\title{
Diversity of macroalgae diversity in the tidal waters
}

\section{Nurfauzi Ahmad (D*, Diana Hernawati, Diki Muhamad Chaidir}

Biology Education, Faculty of Teacher Training and Education, Universitas Siliwangi, Indonesia

"Corresponding author: nurfauzi292@gmail.com

Article Info

Article History:

Received I8 September 2020

Revised I9 October 2020

Accepted 03 December 2020

Published 30 April 202I

\section{Keywords:}

Diversity

Macroalgae

Sancang beach

Tidal waters

\section{ABSTRACT}

The Tidal waters of Sancang beach are habitats for various marine biota, such as macroalgae. This research aims to find out the diversity of macroalgae species in the tidal waters of Sancang Beach, conducted in February-April 2020. This research uses qualitative methods, sampling techniques using purposive sampling with the help of transect belts. The stations used in the search consist of Station I in the Ciporeang area, station 2 in the Cicukangjambe area, and station 3 in the Cibako area. Each station has one 100 meter transect belt with a plot size of I x I meter. Ecological index calculations include diversity index, uniformity index, and dominance index. The results showed that 39 types of macroalgae were found consisting of I0 orders, I8 families, 26 genera with a total macroalgae count was I3324 individuals. The average value of the ecological index obtained includes the diversity index $\left(\mathrm{H}^{\prime}\right) 2.15$ with the medium category, the uniformity index (E) 0.26 with the low category, and the dominance index (C) 0.19 with the low category.

Copyright (C) 202I, Ahmad et al This is an open access article under the CC-BY-SA license

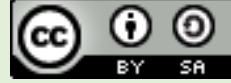

Citation: Ahmad, N., Hernawati, D., \& Chaidir, D.M. (202I). Diversity of macroalgae diversity in the tidal waters. JPBIO (Jumal Pendidikan Biologi), 6(I), 46-54. DOI: https://doi.org/I0.31932/jpbio.v6iI.732

\section{INTRODUCTION}

The presence of macroalgae can be found on almost every tropical beach, especially in Indonesia. Macroalgae have a very important role in coastal ecosystems, this is because macroalgae are the highest supply of oxygen in the oceans. Not only that macroalgae are also a source of food, enlargement place, and a sanctuary for fish and other marine biota (Handayani, 2019). Macroalgae are also an important part of the preparation of coastal ecosystems and maintaining the balance of marine ecosystems (Irawan, Singgih \& Luthfi, 2017). Macroalgae is one of the marine biota that resembles plants, its body parts resemble roots, stems, and leaves as in plants. This part of the macroalgae's constituent body is called the talus. Talus can be filament-shaped, thin leaf layer or giant kelp (Kasanah, Noer, Setyadi, Triyanto \& Trialfihianty, 20I8). Macroalgae live by sticking or attaching to a substrate in an area that has sufficient sunlight. Some types of macroalgae live 
epiphytely (e.g. Enteromorpha flexousa), but most living macroalgae stick to substrates such as sand, corals, rocks, and other massive objects (Eunuch, 2017). This condition is usually found in coastal areas, especially in the littoral zone.

The littoral zone is a land that is visible at low tide, while when the tide occurs the land will be covered by seawater. In line with Kamal, Samsul, Mahdi, Nursalmi \& Humaira (2015) that the littoral zone is a transitional area between ocean conditions and ocean conditions so that various organisms are present in this zone. The littoral zone is also an area that is always hit by waves and affected by tides. Tides occur due to changes or differences in sea levels that occur repeatedly over a certain period, due to the movement of celestial objects i.e. the circulation of the moon around the earth, the circulation of the moon around the sun, and the rotation of the Earth on its axis (Rangkuti, Cordova, Rahmawati, Ani, Yulma \& Adimu, 2017). These waves and tides carry a lot of high oxygen content, thus making this zone overgrown with various types of macroalgae. One of the areas with a fairly large littoral zone is Sancang Beach.

Based on the pre-observation results of Sancang Beach is located in The South Garut area and directly adjacent to Tasikmalaya Regency. Administratively Sancang Beach is part of Leweung Sancang Nature Reserve located in Sancang Village, Cibalong District, Garut Regency, West Java. Sancang Beach itself has an area of I,I50 Ha (BBKSDA Jabar, 2016). The existence of Sancang beach which is part of the Nature Reserve certainly has natural conditions that are still maintained, thus allowing the discovery of a variety of marine biota, most notably macroalgae. Sancang Beach, which is widely known, especially by the people of West Java, needs more attention to show the benefits or role that Sancang beach has for various aspects, especially ecological and other aspects, such as knowledge, economy, and food.

This research was conducted to determine the stability of ecosystems in the waters of Sancang Beach by knowing the diversity of macroalgae types and describing macroalgae ecological index, including diversity, uniformity, and macroalgae dominance in the tidal waters of Sancang Beach Garut Regency. Then, the absence of research on macroalgae conducted in Sancang Beach is also one of the factors implemented by this research. The benefits of this research are expected to be reused into secondary data of further research, identification of the collection types can be used as a source of biological learning, and add insight, as well as the development of potential marine biodiversity resources, especially macroalgae for communities around Sancang beach as well as BBKSDA as the regional management.

\section{RESEARCH METHODS}

\section{Research Design}

This research was conducted in February-April 2020, in the tidal waters of Sancang beach, Garut Regency. This research site is located on the coast of Sancang Beach which has white sandy beach conditions, muddy, rocky, carpeted and there is a large stretch of seagrass field, and there are several rivers in the research site, as seen in Figure I.
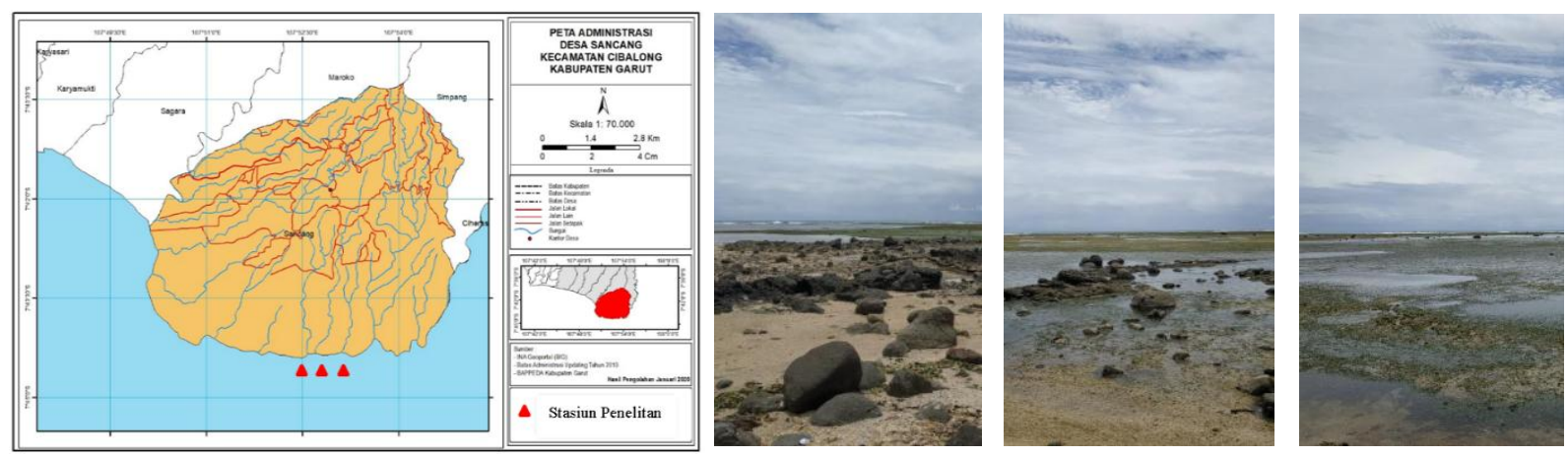

Figure I. Research sites 
The research method used in this study is a qualitative approach that is exploratory with survey techniques (Sudaryono, 2017). The study used a data source consisting of primary and secondary data. Primary data was taken during the study, including data on the type and number of macroalgae individuals, while secondary data was obtained from previously existing relevant data.

\section{Instruments}

The instructions used in the study are I) observation sheets, which are used at the time of observation in the field; and 2) an interview sheet, which serves as one of the instruments for collecting research data in the field; and 3) documentation, which serves as supporting observation data.

\section{Procedures}

Prior to the implementation of the research, preliminary observations have been made in advance to increase information and knowledge about the research location as well as for the determination of research stations. The research station was determined using the purposive sampling technique (Sugiyono, 2016), as many as 3 stations were obtained in different areas with a distance of \pm 300 meters between stations. The first location used as a research station $I$ is Ciporeang area, then the location of 2 research stations Cicukangjambe area and research station 3 Cibako area. The three areas used as research stations are chosen based on different rivers and substrates. Station I has a river and has a substrate of rocks, sand, and dead corals, Station 2 is no river with mud, coral, and sand substrates. While Station 3 there are rivers and substrates of sand and dead coral.

Data collection is assisted by using a transect belt that is pulled vertically from the shoreline towards the sea 100 meters long. Macroalgae samples are then calculated and taken based on representatives of each type of macroalgae located on each plot of the research station. The plot used measures I x I meter, which is a provision for macroalgae samples (Wheater, Bell, \& Cook., 20II). An illustration of the transect belt used is seen in Figure 2.

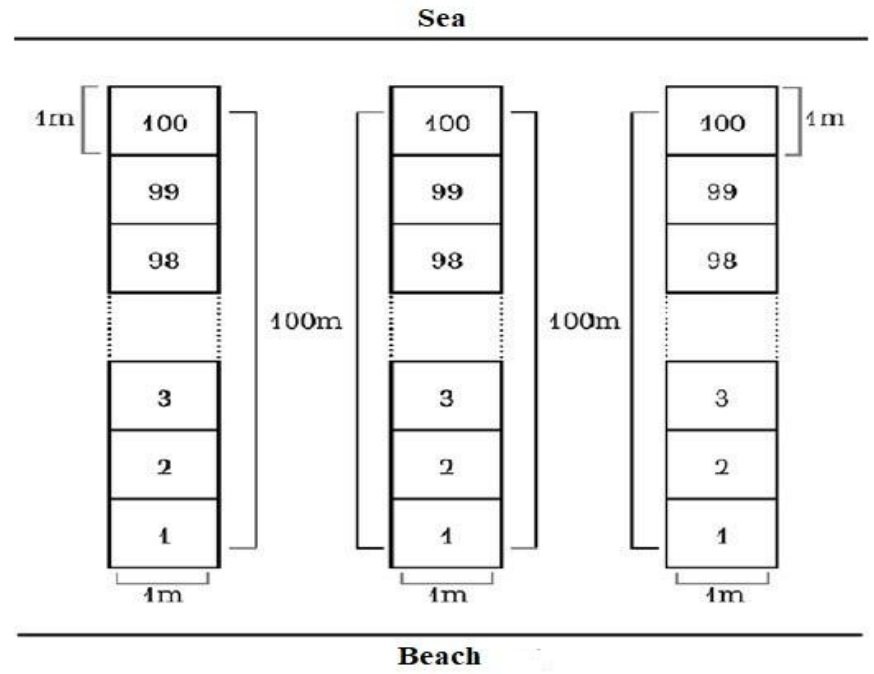

Figure 2. Belt transect method

Macroalgae samples at the research station are calculated based on clumps that are individuals that are still in one unit or stacked (Ist individual) so that when found a clump of the same type but separate then it is counted as the 2 nd individual. Macroalgae found at the research station were taken and counted using the help of tweezers and shovels, then put into plastic specimens that had been labeled. Then, the process of preservation of macroalgae is simply done 
clothesline with the help of sunlight. Then, the identification process is carried out based on morphology, including the form of thallus or color (pigment content) with the help of identification books and relevant websites (Kasanah et al., 2018; Pereira, 2016).

\section{Data Analysis}

The data analysis calculated in this study is an ecological index, covering the diversity index, uniformity index, and dominance index that is part of the ecological statistical analysis (Odum, 1993). The results of the ecological index of macroalgae will be presented in the form of tables and analyzed descriptively.

\section{RESULTS}

Based on research conducted in the tidal waters of Sancang beach, 39 macroalgae species are classified into II orders, I9 families, and 26 genera with a total was I3.324 individuals. After observation, interviews, and documentation, as well as the calculation of macroalgae in the field, several types of macroalgae samples representing each station were taken for identification and classification. The results also showed the presentation of the presence of each type of macroalgae along with the ecological index available on each station.

Based on the research that has been conducted, the acquired ecological index includes the Diversity index Shannon-Weiner $\left(\mathrm{H}^{\prime}\right)$, the Evenness Uniformity index (E), and the macroalgae dominance index $(\mathrm{C})$ at each research station seen in Table I.

Table I. Ecological index observations

\begin{tabular}{cccc}
\hline \multirow{2}{*}{ Station } & \multicolumn{3}{c}{ Ecology Index } \\
\cline { 2 - 4 } & Diversity $\left(\mathrm{H}^{\prime}\right)$ & Uniformity $(\mathrm{E})$ & Dominance $(\mathrm{C})$ \\
\hline I (Ciporeang) & $2.35($ Medium) & 0.27 (Low) & 0.12 (Low) \\
\hline 2(Cicukangjambe) & I.58 (Medium) & 0.20 (Low) & $0.3 \mathrm{I}$ (Medium) \\
\hline 3 (Cibako) & $2.5 \mathrm{I}$ (Medium) & 0.30 (Low) & 0.13 (Low) \\
\hline Average Amount & $2.15($ Medium) & 0.26 (Low) & 0.19 (Low) \\
\hline
\end{tabular}

The spread of macroalgae in the form of percentage diagrams found in station I (Ciporeang) can be seen in Figure 3.
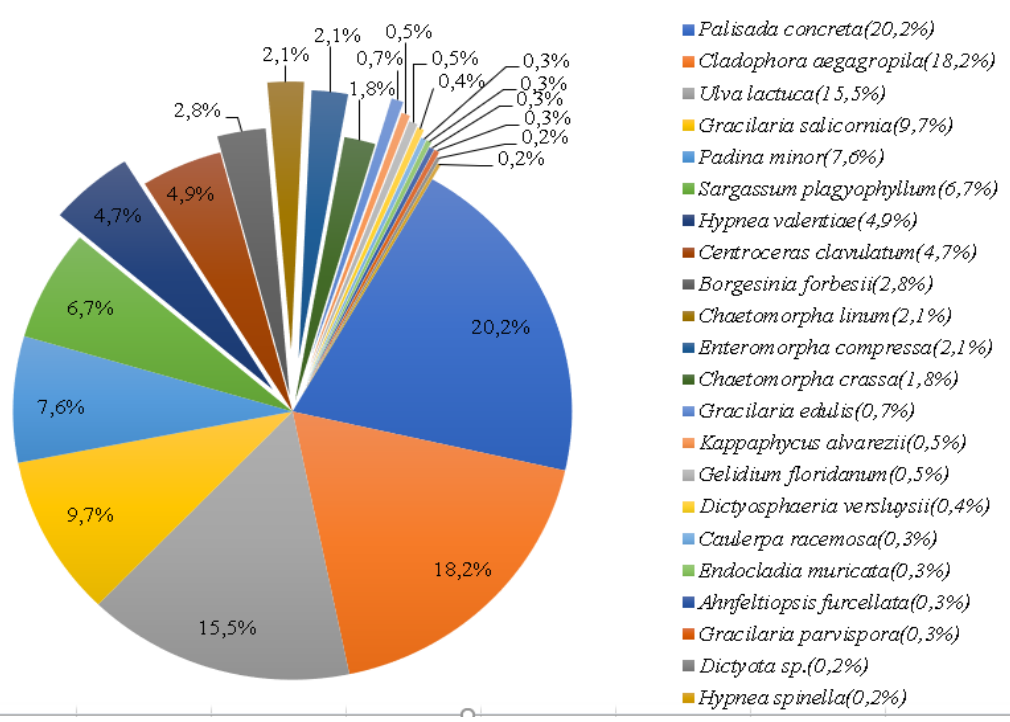

Figure 3. Macroalgae spread presentation station I (Ciporeang) 
The spread of macroalgae at the station is seen in Figure 4.
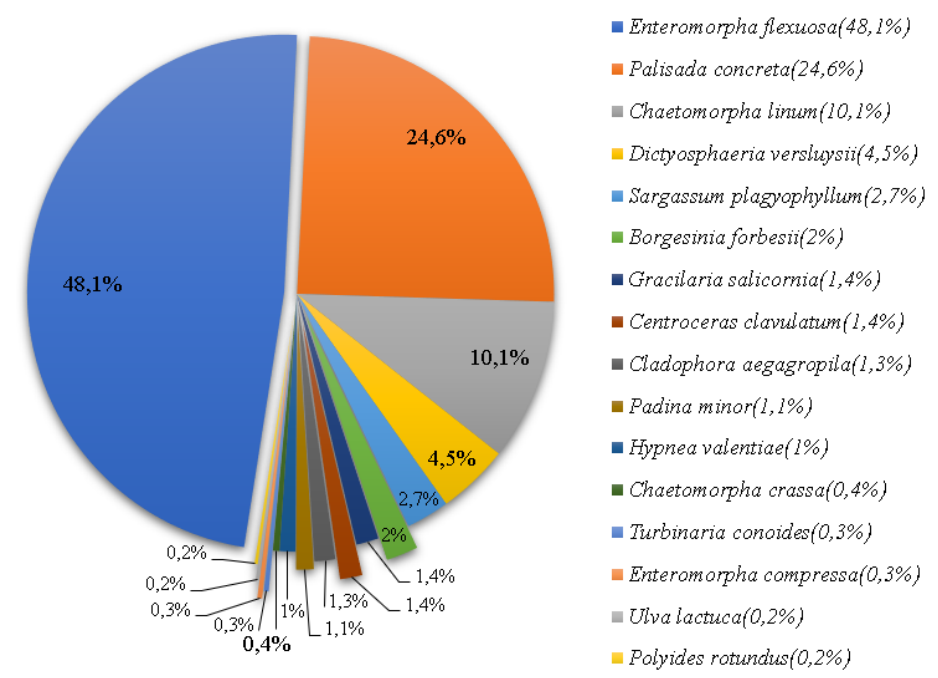

Figure 4. Macroalgae distribution percentage station 2 (Cicukangjambe)

Furthermore, the percentage of macroalgae distribution at station 3 (Cibako) is seen in Figure 5.

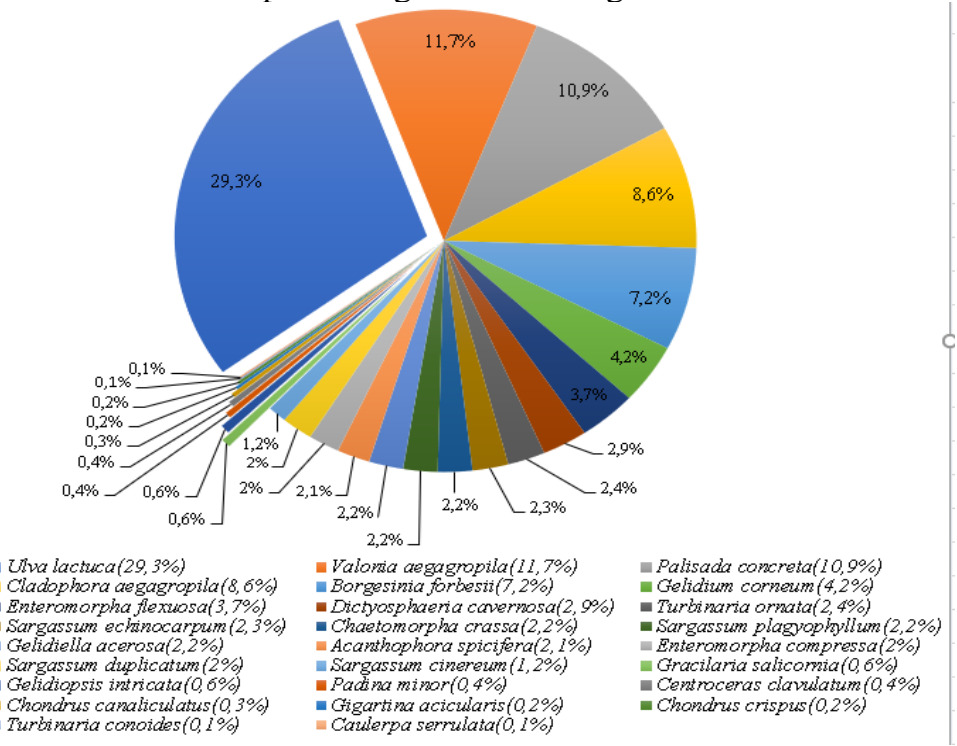

Figure 5. Macroalgae Distribution Percentage Station 3

\section{DISCUSSION}

Based on Figure 3, it is known that at station I there were 22 types of macroalgae consisting was 5.857 individuals. The species with the highest number of individuals are found in the species Palisada concreta with a total was I.I83 individuals. Meanwhile, the type with the lowest number of individuals found at this station is the species Hypnea spinella with several I2 individuals.

The number of individuals found at this station is due to the location adjacent to the river flow, where the river carries nutrients such as nitrates derived from human activity. Following Anderson, Schluter \& Aertbjerg (2006) that coastal waters receive a large load of organic and inorganic material inputs. This material is very important in the growth and development of macroalgae in their habitat. According to Ibrahim, Yusuf, Surtikanti, Riandi \& Adianto, (20I4) that an organism can abundant its existence if environmental factors can support the existence of 
the living being. So at this station, many macroalgae individuals are found due to abundant sources of nutrients.

Station $I$ is located in the Ciporeang area is the closest location from road access to Sancang beach with coordinate point I07052'26" BT - 7044'24" LS. This station is often used as a place for locals to look for shrimp and fish because next to Station I (Ciporeang) to the west there is a lagoon when it recedes. Not a few people are also looking for macroalgae at this station to be used as support for their lives. The discovery of macroalgae in this station is not separated from the presence of important components that support macroalgae growth. Where coastal conditions have dead and sandy coral substrates are the main habitat for macroalgae to grow and develop.

Based on Figure 4. It is known that at station 2 there were 17 types of macroalgae consisting is 2.720 Individuals. The species with the highest number was found in the Enteromorpha flexuosa species with a total of 1.307 individuals (48.1\%). Meanwhile, the species with the fewest number is found in the species Ulva lactuca with the number of 4 individuals ( $0.2 \%)$ only.

There are at least a number and types of macroalgae in this station because there are other individuals that dominate here, namely Snake stars and Nereis (seaworms) thus affecting the presence of macroalgae at this station. Following Ibrahim et al., (20I4) states that an organism can survive, reproduce or perform other life activities we can see from its pattern of interaction with other organisms. Then this macroalgae is also a food source for sea snake stars, based on Aziz \& Aznam (1996) Algae, algae scavenging, and sponges are food sources for certain sea snake stars. Therefore, the growth and development of macroalgae at this station are not directly proportional to the need to eat a large number of star snakes, so the presence of macroalgae at this station is not so abundant and diverse than other stations.

Station 2 located in the Cicukangjambe area is located after Station I (Ciporeang) when viewed from the entrance of Sancang Beach. The station has coordinate point I07052'38" BT 7044' I9" LS. Seagrass fields, mud, sand, and dead corals are the dominant constituents of this area as seen in Figure 4, very few people do activities in this location, because there are many stars of sea snakes and nereis and the locals do not know how to use them.

Based on Figure 5, it is known that at station 3 there were 26 types of macroalgae with a total of 4,747 individuals. The species with the highest number was found in the Ulva lactuca species with a total of 1393 individuals (29.3\%). This is because Ulva lactuca belongs to the Chlorophyceae class which is widely found in the intertidal or subtidal zone (Asmida, Akmal, Ahmad \& Diyana, 2017), which we better recognize as the tidal zone. Meanwhile, the species with the fewest number is found in Caulerpa serrulata species with the number of 2 individuals (0.1\%) only. According to research conducted Wulandari, Hutabarat, Sahala \& Ruswahyuni (20I5) in the waters of Pulau Panjang that the existence of Caulerpa serrulata type is also the least found. This is because the place or media for macroalgae settles, i.e. the presence of coral fragments that are in coastal niches is very few.

Station 3 located in the Cibako area is the most remote location from Sancang entrance access, with coordinate point I07052'9" BT - 7044'I9" LS. This location has conditions that are not different from station I which is the condition of sandy, rock, and dead coral, as well as mud, being the constituent of this area. It has the highest currents and waves than other stations and is located near rivers such as station I. This condition makes station 3 (Cibako) has a considerable number of macroalgae and a diverse variety of types. In the I.2 and 3 overall research stations, the most macroalgae species were palisade concreta species with a total of 2,368 individuals. While the least macroalgae type is found and there is only found at Station 3 (Cibako).

Based on Table I, it is known that each station has a medium diversity index, which this category indicates that the ecosystem in the waters of Sancang Beach is still quite maintained. Then 
for uniformity, each station is in a low category, where the uniformity at each station is not equal or uneven. The dominance of Stations I and 3 has a low category, meaning the absence of dominance at this station, while station 2 is in the medium category, this is because at station 2 there is the most dominating type.

The value of the diversity index obtained from all stations is above the number I and below the number 3. This value according to the Shannon-Wiener index belongs to the medium category, meaning the overall research stations I, 2, and 3 have diversity in the medium category. According to Sirait, Marlenny, Rahmatia, Firsty \& Pattulloh (2018), the diversity index is showing that the condition of the ecosystem is in a medium state as well, although it may be indicative of ecological pressures. Thus, the analysis of diversity index data at each research station indicates that the environmental conditions in the tidal waters of Sancang Beach are still good enough for macroalgae life. '

Although the results of the data analysis on the diversity index all show in the medium category. However, the highest score is found at station I (Ciporeang) and followed by Station 3 (Cibako), while Station 2 (Cicukangjambe) has the lowest score. This is because at Station 2 (Cicukangjambe) other organisms dominate the area causing some macroalgae to be selected or unable to adapt. Besides, Station 2 (Cicukangjambe) located away from the river also affects the presence of nutrients as supporting macroalgae growth. While at Stations I and 3 there are no other organisms that dominate there, and its proximity to the river is a major factor in the diversity of macroalgae there. This is by Utami, Maslukah, Lilik \& Yusuf (2016) that nutrients namely phosphate and nitrates have a very vital role in macroalgae growth. Thus a high diversity value is found in areas that have rivers and no other organisms dominate.

The Evenness uniformity index is used to indicate the abundance of individuals evenly or not in an ecosystem. The uniformity index ranges from 0 to I. If the uniformity index value is close to 0 it indicates that the individual spread of each species is not equal or uneven. Meanwhile, if the uniformity index value is close to I then the spread of individuals in the ecosystem is evenly distributed or relatively the same (Odum, 1993). Based on Table I the evenness uniformity index value at each research station belongs to a low category and the value that each station has does not differ much. So, each research station has an uneven or unequal individual distribution. The macroalgae type diversity in this study is in the medium category. Sirait et al. (2018) explain that the higher the value of diversity the lower the value of uniformity or the closer zero. Therefore, each macroalgae individual also has different adaptation capabilities. Jayadi (2015) statement that the types that have been well adapted to all environmental conditions can spread widely. Therefore the uniformity index in tidal waters is in a low category, in the sense that the spread of individuals is uneven.

The dominance index in this study was used to determine the extent to which a type of macroalgae group dominated the other group. This dominance index ranges from $0-\mathrm{I}$. If the value of the dominant index obtained is close to 0 , then there is no dominance of a type in the area, but if the value obtained is close to I, then there is a type of macroalgae group that dominates the area. Thus, if an area found individual dominance, then the value of diversity in the area will also fall (Odum, 1993).

Based on Table I, it can be concluded that stations I (Ciporeang) and 3 (Cibako) are not found to dominate because the value obtained is close to 0. Station 2 (Cicukangjambe) has the highest value for the dominance index than other stations, this is because of the discovery of macroalgae types with high adaptation and dominating the area. So if many types of macroalgae dominate at station 2 (Cicukangjambe), then the diversity at the station will decrease and be disturbed. According to Insafitri (2010) that considerable dominance will lead to a lame community. 


\section{CONCLUSION}

Based on research that has been conducted in the tidal waters of Sancang Beach, Garut Regency, West Java, it was concluded that the research that has been conducted at three stations, namely station I (Ciporeang), station 2 (Cicukangjambe), and station 3 (Cibako), obtained 39 types of macroalgae with different morphology and classifications. The macroalgae community in the tidal waters of Sancang beach consists of II orders, I9 families, and 26 genera of how many species with a total number of individuals was 13.324. Later, the macroalgae of the family Sargassaceae was a macroalga that dominated the tidal waters of Sancang beach. Ecological index values include the diversity index in the medium category $\left(\mathrm{H}^{\prime}=2.15\right)$, the evenness uniformity index value in the low category $(\mathrm{E}=026)$, and the dominant index value in the low category $(\mathrm{C}=0.19)$. The implications of this study can be used as secondary data for future research, biological learning resources, or as macroalgae utilization for communities around the coast.

\section{ACKNOWLEDGMENT}

Thank you researchers to the various parties who have supported the progress and complete of this research. Especially the researcher thanks you to biodiversity and conservation study group (KSBK), Universitas Siliwangi. Especially Ika Ramdana Bancin, Chestalita Oktaviana, Ika Raymita Husna, Pujiati Nurachman, Rina Maryani, Taufik, Nurul, Dedi Koswara, Virdan, Fahmi, Sendi and Eri.

\section{REFERENCES}

Anderson, J.H., Schluter, \& Aertbjerg, G. (2006). Coastal eutro-phication: recent developments in definitions and implications for monitoring strategies. Journal of Plankton Research, 28(7), 62I-628. Retrieved from https://doi.org/I0.I093/plankt/fbl0I4

Asmida, I., Akmal, A.B.N., Ahmad, I., \& Diyana, M.S. (2017). Biodiversity of macroalgae in blue lagoon, the straits of malacca, malaysia and some aspects of changes in species composition. Science Malaysiana, 46(I), I-7. Retrieved from http://dx.doi.org/I0.17576/jsm-2017460I-0I

Aziz, \& Aznam. (1996) Food and how to eat different types of stares. Center for Research and Development of Marine Biology, Center for Research and Development of Oceanology, $X X I(3)$, I3-22. Retrieved from http://oseanografi.lipi.go.id/dokumen/oseana_xxi(3)I322.pdf

Jabar Natural Resources Conservation Center. (2016). Bbksda scope conservation area information, 89-90. Retrieved from https://bbksdajabar.ksdae.menlhk.go.id

Handayani, N.A. (2019). Inventory and macroalgae distribution pattern on rock substrate at gunung kidul kukup beach yogyakarta. Muhammadiyah University of Surakarta.

Ibrahim, Yusuf, Surtikanti, H.K., Riandi., \& Adianto. (20I4). Analysis of biota diversity and physical-chemical factors of karapyak pangandaran beach for the development needs of integrated field lectures of prospective biology teachers. Proceeding Biology Education Conference, II I I , I4-I26. Retrieved from http://www.neliti.com/id/publications/I71769/analisis-keragaman-biota-dan-faktor-

fisiko-kimia-pantai-karapyak-pangandaran-unt

Insafitri. (2010). Bivalves diversity, uniformity, and dominance in the lapindo muara sungai porong mud dump area. Jurnal KELAUTAN, 3(I), 54-59. Retrieved from https://doi.org/I02II07/jk.v3iI.843

Irawan, Singgih, \& Luthfi, O.M. (2017). Identification of macroalgae species in porites coral micro atoll in kondang merak beach, malang regency. Rinjani Scientific Journal, 5(I), 40-46. Retrieved

from 
http://www.researchgate.net/publication/3I262I642_Identifikasi_Jenis_Makro_Alga_Pa da_Mikro_Atoll_Karang_Poriotes_di_Pantai_Kondang_Merak_Malang Jayadi, E.M. (2015). Plant ecology. Mataram: State Islamic Institute (IAIN) Mataram.

Kasanah, Noer, Setyadi, Triyanto, \& Trialfihianty, T.I. (2018). Indonesian seaweed (seri I). Yogyakarta: Gadjah Mada University Press.

Eunuch, M. (2017). Macro algae. Jakarta: Penebar Swadaya Group.

Ministry of Environment (KLH). (2004). Decree of the minister of klh no.5I/2004 on marine water quality standards for marine biota. KLH, Jakarta.

Odum, E.P. (1993). Ecological basics. Yogyakarta: Gadjah Mada University Press.

Pereira, L. (2016). Edible Seaweeds of the World (Ist ed.). Boca Raton: CRC Press.

Rangkuti, A.M., Cordova, M.R., Rahmawati, Ani, Yulma, \& Adimu, H.E. (20I7). Indonesian coastal and marine ecositem. Jakarta: Bumi Aksara.

Kamal, Samsul, Mahdi, Nursalmi, \& Humaira. (2015). Coral diversity in the litoral zone of iboih waters of sukakarya district of sabang city. Biotic Journal, 3(I), 45-56. Retrieved from http://dx.doi.org/I0.22373/biotik.v3iI.99I

Sirait, Marlenny, Rahmatia, Firsty, \& Pattulloh. (2018). Comparison of Diversity and Phytoplankton Dominance Index in Ciliwung River Jakarta. Marine Journal, II(I), 75-79. Retrieved from https://doi.org/I0.2II07/jk.vIIiI3338

Sudaryono. (2017). Quantitative, qualitative, and mix method research methodology. Depok: Rajawali Pers.

Sugiyono. (2016). Quantitative, qualitative and r\&d research methods. Bandung: PT Alfabet.

Utami, T.M.R., Maslukah, Lilik, \& Yusuf, M. (2016). Distribution of nitrate (NO3) and phosphate (PO4) in karangsong peraiaran indramayu regency. Marina Oceanographic Bulletin, $5 . \quad$ Retrieved from http://ejournal.undip.ac.id/index.php/buloma/article/view/I I 293

Wulandari, S.R., Hutabarat, Sahala., \& Ruswahyuni. (2015). Pengaruh arus dan substrat terhadap distribusi kerapatan rumput laut di perairan pulau panjang sebelah barat dan selatan. Diponegoro Journal of Maquares, Management of Aquatic Resources, 4(3), 9I-98. Retrieved from http://ejournal.undip.ac.id/index.php/maquares/article/view/9324

Wheater, C.P., Bell, J.R., \& Cook, P.A. (20I I). Practical field ecology: A project guide. Hoboken: Willey-Blackwell. 